\title{
PREDICTING RISK OF COLLISION FOR OIL TANKERS IN THE GULF OF FINLAND
}

\section{PREDYKCJA RYZYKA KOLIZJI TANKOWCÓW PRZEWOŻĄCYCH ROPĘ PO WODACH ZATOKI FIŃSKIEJ}

\author{
Jakub Montewka \\ Helsinki University of Technology, Department of Applied Mechanics, \\ Marine Technology, 02015 Espoo, Finland \\ e-mail: jakub.montewka@tkk.fi
}

\begin{abstract}
Gulf of Finland (GOF) is considered one of the most dense place in the world in terms of marine traffic, and in addition to the Danish Straits it forms the narrowest and shallowest waters in the Baltic Sea. As the volume of shipping in the GOF increases constantly, so does the risk of accidents. This paper presents a model for risk assessment for vessels colliding with emphasis put on tankers. A new adaptation of pre-existent physical model based on molecular collision theory for probability of collision assessment is presented. The consequences of an accident are expressed in the monetary terms, and concern the costs due to an oil spill. Neither loss of humans' life nor structural damages were considered in the presented risk model. The risk that colliding tankers pose are assessed for winter and traffic summer profiles separately.
\end{abstract}

Keywords: risk assessment, collision probability, maritime traffic safety, Gulf of Finland.

Streszczenie: Zatoka Fińska jest uważana za jedno z tych miejsc na świecie, które charakteryzują się największą intensywnością ruchu morskiego, a oprócz Cieśnin Duńskich stanowi najwęższy i najpłytszy szlak wodny w akwenie Morza Bałtyckiego. Ponieważ intensywność ruchu statków na obszarze Zatoki Fińskiej ciagle rośnie, zwiększa się również ryzyko wypadków. W niniejszym artykule przedstawiono model dla oceny ryzyka związanego z kolizją statków, ze szczególnym uwzględnieniem tankowców. Przedstawiono nowe zastosowanie znanego wcześniej modelu fizycznego opartego na teorii kolizji molekularnych oraz użycie tego modelu do oceny prawdopodobieństwa kolizji statków. Konsekwencje takiego wypadku są wyrażone jako koszty materialne i związane są ze stratami spowodowanymi przez wyciek ropy. W zaprezentowanym modelu ryzyka nie uwzględnia się start życia ludzkiego ani szkód materialnych poniesionych przez armatorów. Ryzyko związane z kolizją tankowców oceniono oddzielnie dla letniego i zimowego profilu pogodowego.

Słowa kluczowe: ocena ryzyka, prawdopodobieństwo kolizji, bezpieczeństwo żeglugi morskiej, Zatoka Fińska. 


\section{Introduction}

The Gulf of Finland is said to be one of the most dense operated sea areas in the world, with dense passenger and cargo traffic of which petroleum conveyances have a share of over $50 \%$. It is widely believed that the growth of maritime transportation will continue also in the future [5]. The huge rise in traffic is far beyond what experts had forecast. At the beginning of the decade, it was estimated that by year 2010, an annual amount of oil transported through these sea lanes would be like 75 million tones. Last year more than 150 million tones were shipped through the GOF and the latest estimate for 2010 is 250 million tones [5], [9]. As it may be noticed, the traffic in the Baltic area has not only increased, but the nature of the traffic has also changed rapidly, the increase of oil transportation strongly increases the risks for oil spills, and this is predicted to continue as well [8], [11]. Other features which distinguish the GOF from other sea areas and, which can not be neglected while analyzing the risk of maritime traffic in the GOF are the harsh winter conditions, which significantly influences the number and types of accidents [4].

In this paper author took up the challenge of marine traffic risk assessment in selected area of the GOF, with emphasis put on accidents which involve double hull tankers. The presented study concerns a junction between Helsinki and Tallinn. The risk is calculated in the yearly perspective for the whole analyzed area and is expressed as a product of an accident probability and its consequences, where the latter are the product of an oil spill probability given the accident and costs of the oil spill. Innovative use of a model for collision probabilities assessment may be recognized in this paper.

\section{Maritime traffic profile in the Gulf of Finland}

The sea area under consideration in this study is the junction of two main waterways in the GOF; one leads N-S and the other E-W. The N-S stream consists mainly of passenger vessels cruising between Helsinki and Tallinn, whereas the E-W stream consists of cargo vessels bound for and from harbours located in the GOF. The vessel traffic profiles over the area under analysis are described using data derived from the AIS transmissions recorded in March and July 2006. To estimate the total number of vessels that arrive in and depart from the GOF, counting gate number 1 was established along meridian $023.5^{\circ} \mathrm{E}$. To compute the precise traffic volumes of the streams in the junction, another two counting gates were established. Gate number 2 was established along parallel $60^{\circ} \mathrm{N}$ to count N-S traffic, and 
gate number 3 along the meridian $026^{\circ} \mathrm{E}$ to count E-W traffic (Fig. 1). The marine traffic in this area was assumed to consist of four main flows: east, west, north, and south, while the north and south flows are assumed to contain passenger vessels only. Each flow was modelled with the following input parameters: overall number of vessels, type of vessels, number of vessels of a given type, size of vessel of a given type, speed of vessels of a given type, course of vessel, and position of vessel across the waterway. For modelling purposes most of these values were approximated by continuous distribution or by histograms. The distribution of the features being analysed was chosen according to the results of a chi-square test. Those which fitted best (obtained the highest value of chi-square test) were selected as inputs for the model. In some cases, if none of the available distributions fitted then recorded discrete values were taken into the model, by random sampling.
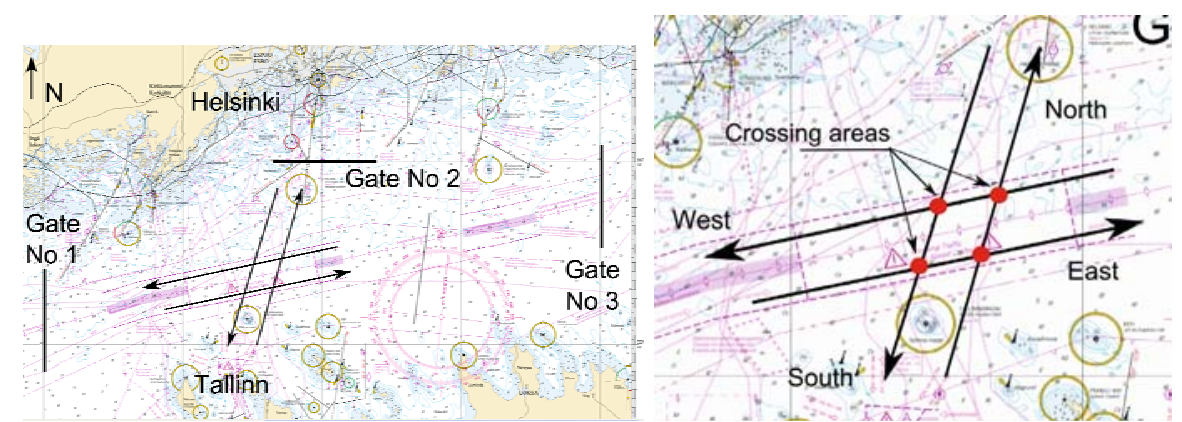

Fig. 1. Waterways junction that was analysed with counting gates (to left) and main traffic flows (to right) marked

The types of vessels and their percentage share of the traffic in the GOF are presented graphically in Fig. 2. The diagram constitutes the results of two months of AIS transmission recordings, carried out in March and July 2006 at counting gates numbers 1 (all vessels) and 2 (passenger vessels only). The traffic recorded in March was considered the winter profile of traffic, whereas the traffic registered in July was a summer profile of marine traffic in the GOF. 


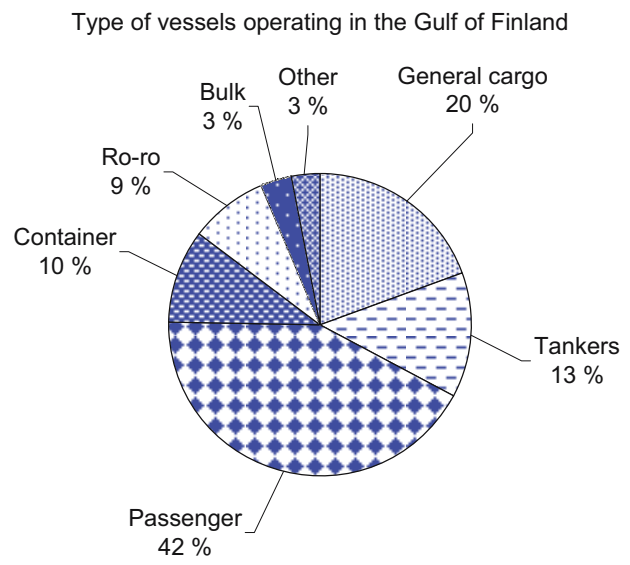

Fig. 2. Types of vessels operating in the GOF in the year 2006 [7]

No significant differences in the number of vessels passing gate 1 during each season (winter, summer) were observed, except tankers (Fig. 3). However, such differences exist for gate 2. The main reason for the difference is that during wintertime the operations of high-speed craft between Helsinki and Tallinn were suspended, and therefore the number of passenger vessels on the above route was reduced.

Although the number of vessels passing gate 1 was similar throughout the year, the spatial distribution of traffic varied this depended mostly on icing conditions in the area. The differences in the distributions were significant and could not be omitted in risk analysis [7]. The above relations hold true for the other gates as well. For the purposes of safety assessment and traffic modelling the traffic spatial distributions may be approximated either by statistical distribution, or by histograms, if the recorded traffic fits any common distribution poorly.

\subsection{Tanker traffic profile}

Tankers traffic in the GOF was assumed to consist of two major types of vessels: crude oil tankers $(25 \%)$ and oil product tankers $(70 \%)$, the remaining 5\% includes chemical and gas tankers which are not considered in the present analysis (Fig. 3). The numbers of tankers recorded in the March and July 2006 differed, therefore the assumption was made that tanker traffic was season dependent, it hold true in terms of number of vessels not their dimensions. The distribution of tanker types and numbers according to season is presented in Fig. 3. 
Predykcja ryzyka kolizji tankowców......

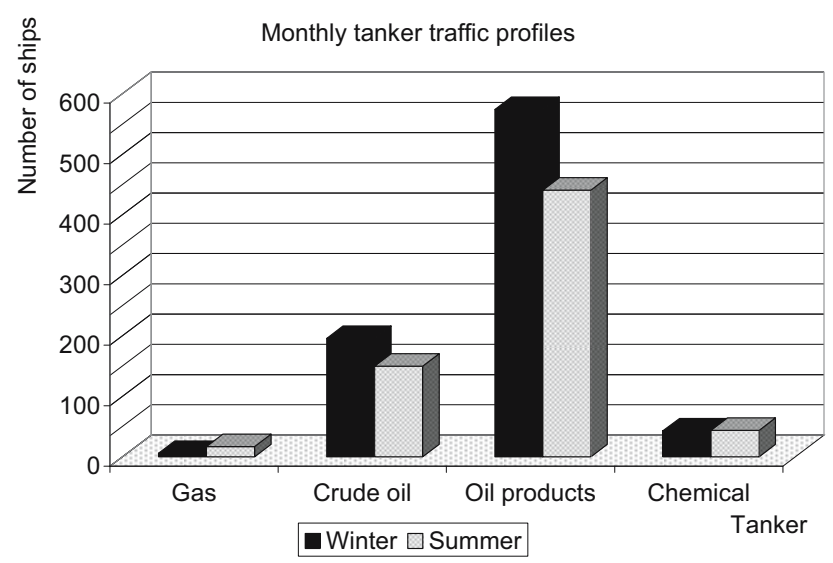

Fig. 3. The traffic profiles of tankers in the GOF

It was assumed, for modelling purposes that the main dimensions of tankers (their length, breadth and maximum design draught) were estimated with use of triangle distributions, which fitted best the observed discrete data. Velocity of the tankers was modelled by a Logistic distribution, which fitted best the recorded values (Fig. 4), and follows the formula:

$$
v=f(x)=\frac{\sec h^{2}\left(0.5\left(\frac{x-\alpha}{\beta}\right)\right)}{4 \beta}
$$

where sech is a hyperbolic secant function, $x$ is a random variable (velocity), $\alpha$ is a location parameter and equals 12.7 , and $\beta$ is a scale parameter which equals 1.2. The courses of the vessels were modelled by either distributions or a sampling method from the recorded AIS data.

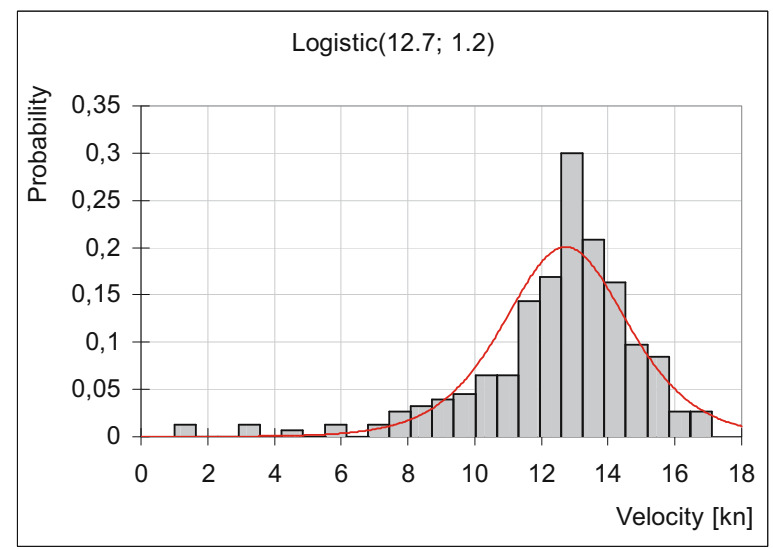

Fig. 4. Histogram of tankers' velocities with Logistic distribution as the probability density function, which fitted best 


\section{Probability of collision modelling}

Probability of ship colliding was modelled by means of original model, which have been developed by the author. A model which assesses the probability of collision is a geometrical model, which combines a molecular collision theory with ship domain theory and a ship dynamics. The model was described in details in [7], therefore and only the main ideas are mentioned in this paper. The model uses the common definition of the probability of a collision, which follows the equation:

$$
P=N_{A} P_{C}
$$

where $N_{A}$ is the geometrical probability of a collision course and $P_{C}$ is the causation probability, also called the probability of failing to avoid a collision when on a collision course. A ship on a collision course is called a collision candidate, which may end up as a collision as a result of technical failure or human error. The causation probability quantifies the proportion of cases in which a collision candidate ends up as a collision. The value of the causation probability for this analysis is adopted from a state-of-the-art model based on a Bayesian Belief Network developed in earlier research [1], [2], [4], [10]. The following values were adopted for: 1.3E-04 for vessels being on crossing courses and 4.9E-05 for head-on and overtake situations.

\section{Modelling of accidental oil outflow from tankers}

The process of modelling an accidental oil spill from tankers presented in this paper consists of four steps as follows:

- on the basis of AIS the fleet of tankers operating in the GOF was described,

- on the basis of tanker sizes the probability of oil outflow in case of accident was calculated,

- the probability of no spill in case of accident was estimated,

- the costs of spill were estimated.

The deadweight of a tanker as a function of her length is presented in Fig. 5, these data were derived from the AIS records carried out in March and June 2006. A function that fitted best the discrete recorded data was a power function, which form is as follows:

$$
D W T=f(L p p)=0.0015 L p p^{3.3008}
$$


where $D W T$ is a tanker's deadweight, $L p p$ is a tanker's length between perpendiculars.

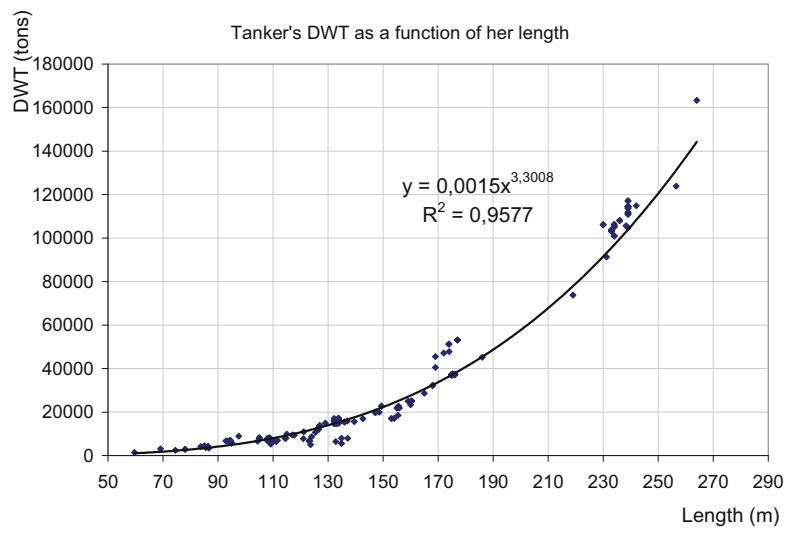

Fig. 5. Baltic Sea tankers DWT as a function of the length, observed data with power function fitted

Probability of oil outflow was calculated for double hull tankers only and it was assumed that the lognormal distribution provided an adequate representation of oil spill volume data [14]. When performing the calculations mean outflow considering there is a spill was computed by means of modified IMO methodology [12], [13]; and standard deviation was calculated based on the assumption that one in 100 casualties where a cargo tank is damaged would lead to loss of entire cargo deadweight. The parameters of lognormal distribution for certain types of tankers are presented in Table 2.

Table 1. The parameters of distribution oil outflow for certain types of tankers [12]

\begin{tabular}{|c|c|c|c|c|}
\hline $\begin{array}{c}\text { Tankers } \\
\text { DWT } \\
\text { (tons) }\end{array}$ & $\begin{array}{c}\text { Mean value for } \\
\text { side damage } \\
\text { (tons) }\end{array}$ & $\begin{array}{c}\text { Standard } \\
\text { deviation }\end{array}$ & $\begin{array}{c}\text { Mean value for } \\
\text { bottom damage } \\
\text { (tons) }\end{array}$ & $\begin{array}{c}\text { Standard } \\
\text { deviation }\end{array}$ \\
\hline 10000 & 811 & 2.94 & 539 & 3.52 \\
\hline 35000 & 3423 & 2.70 & 2093 & 3.37 \\
\hline 50000 & 5231 & 2.64 & 2971 & 3.38 \\
\hline 75000 & 8643 & 2.53 & 4345 & 3.42 \\
\hline 115000 & 15143 & 2.36 & 6309 & 3.52 \\
\hline 150000 & 21881 & 2.29 & 7791 & 3.61 \\
\hline
\end{tabular}

The regression formulae used for the assessment of the mean value of oil outflow volume in case of collision and grounding are presented in Fig. 6. The discrete data for five typical sizes of tanker obtained by means of the 
IMO modified methodology in case of collision and grounding was plotted and the best fits were found. In both cases the polynomials of second order showed a good agreement with calculated data, and were used for further modelling.

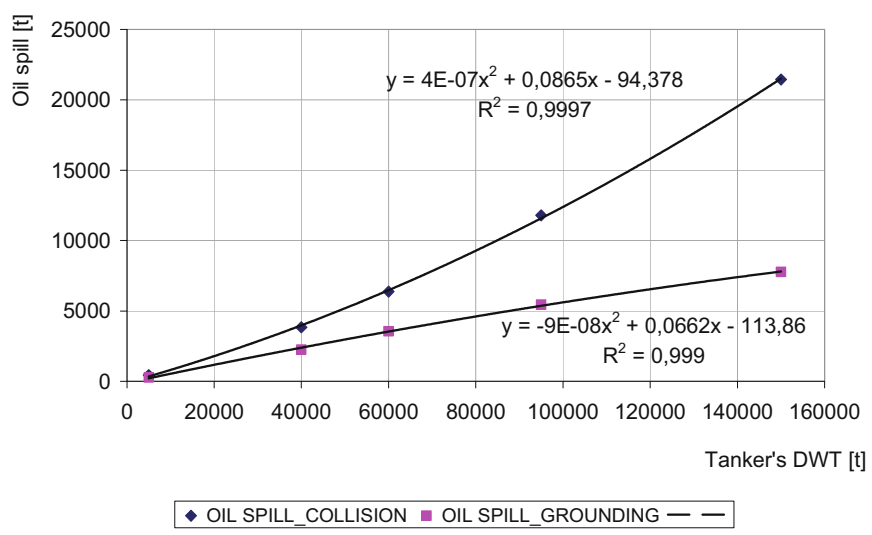

Fig. 6. The values of mean oil outflow from tanker due to collision or grounding, considering there is a spill

On the basis of tabulated value of the standard deviations for certain types of tanker presented in Table 2, the general formula to calculate this value in case of collision was derived as follows:

$$
\sigma_{C O L L}=6.99 D W T^{-0.092}
$$

In the next step, on the basis of formerly defined parameters of the lognormal distributions as a function of tanker's deadweight, the Monte Carlo simulations with 10000 iterations were run. As a result the discrete values were obtained which described the probability of an oil spill of certain size, taking into account the size and frequency of tankers of given size navigating in the GOF. The continuous distributions that fitted best these discreet data both for winter and summer traffic conditions were Pareto 2 distributions. Henceforth the probability density function of oil spill volume $\left(P_{O S}\right)$ in the GOF is expressed as follows:

$$
P_{O S}=f(x)=\frac{q b^{q}}{(x+b)^{q+1}},
$$


where $q$ is 1.9 for summer and 8.4 for winter, $b$ is 9009.1 for summer and 49459.0 for winter, $x$ is a volume of spill size in tons. The appropriate probability density functions are depicted in Fig. 7.
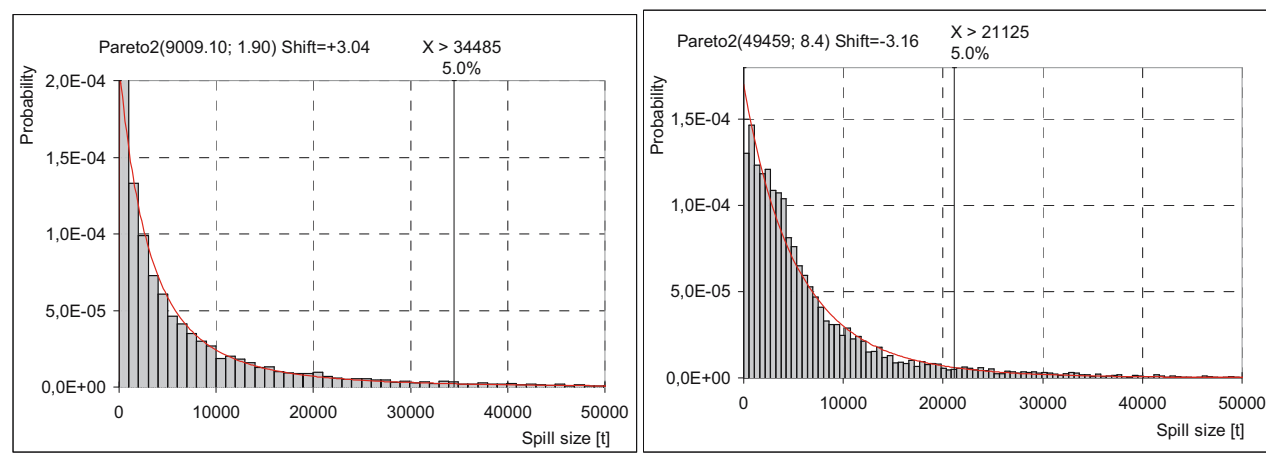

Fig. 7. The probability of an oil spill from the tankers operating in the GOF in case of collision, estimated by Pareto2 distributions for summer (to left) and winter traffic (to right)

The probability of no spill ( $\left.P_{Z E R O} O S\right)$ refers to the likelihood of no spill in all potential collision and grounding scenarios, and the following values were adopted [6]:

- for collision: 0.86 irrespective of tanker's size,

- for grounding:

○ for tankers of 40000 DWT: 0.94,

○ for tankers of 150000 DWT: 0.73 .

In the risk analysis process, it is more useful to use the conditional probability of spill given an accident $\left(P_{O S \mid A}\right)$ instead of the probability of no spill (PERO_OS $)$, and it is expressed as follows:

$$
P_{O S \mid A}=1-P_{\text {ZERO_OS }}
$$

For the purposes of economic quantification of an oil spill, the regression analysis between the cost of an oil spills and the volume of the oil spilled was carried out using historical oil spill data from tankers reported by International Oil Pollution Compensation Funds [16]. A nonlinear regression formula was estimated from the historical data, and the following equation for oil spill cost estimation was arrived at [3]:

$$
C=35951 W^{0.68}
$$

where $C$ denotes a total cost of an oil spill in USD, and $W$ a weight of the oil spill in tons. 


\section{Risk assessment}

Risk may be expressed in several ways, by distribution, expected values, or single probabilities of specific consequences, but probably the most commonly used is the expected values [15]. Approach presented in this paper uses the latter that describes the risk, which was considered a random variable. Expressing the random variable risk as a distribution is very useful, it takes into account uncertainties of input values, and seems mode accurate than single value. The risk that tankers colliding or grounding posed to the environment was calculated using the following formula:

$$
R=P_{A} \cdot P_{O S \mid A} \cdot P_{O S} \cdot C,
$$

where $P_{A}$ means a probability of accident (collision), and the others factor were defined in Chapter 4 . The generic diagram of the risk assessment process implemented in this study is shown in the Fig.8.

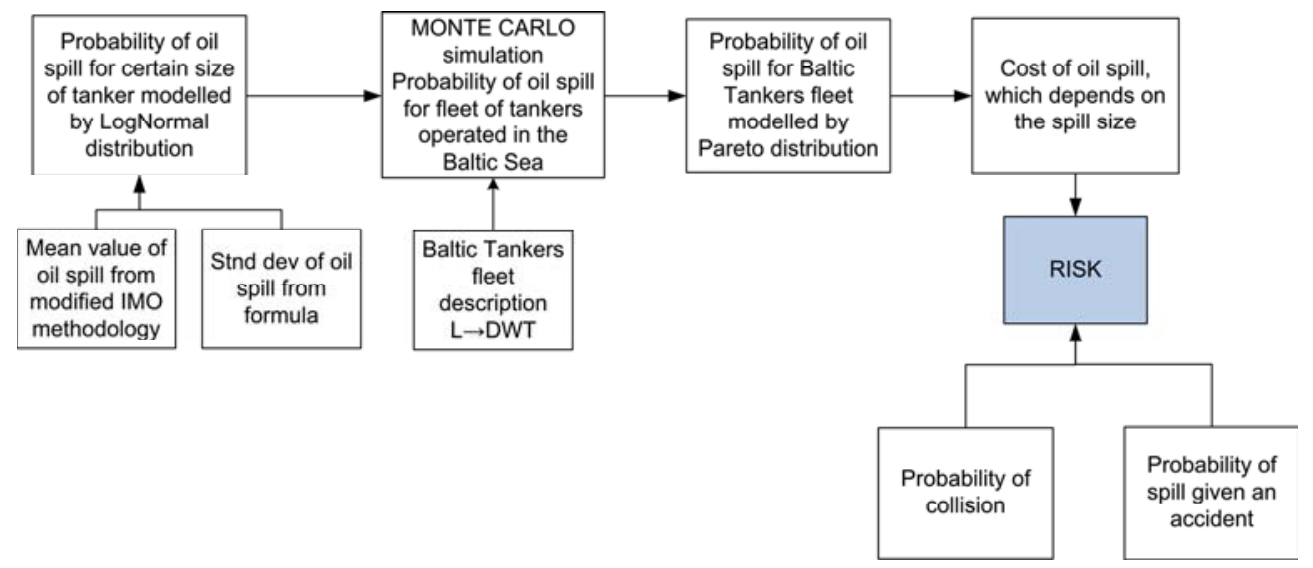

Fig. 8. Block diagram of risk assessment process applied in presented study

The expected numbers of collision candidates, collision probability, and a mean time between collisions are shown in Table 2 . The estimated yearly mean volumes of oil accidentally spilled to the sea due to collision are shown in Table 3. Presented data concerns the annual volume of traffic in the junction between Helsinki and Tallinn only, and were computed separately for summer and winter traffic conditions. The oil spill volume concerns double hull tankers only. 
Predykcja ryzyka kolizji tankowców......

Table 2. Estimates of collision candidates number, collision probability and collision reoccurrence for tankers in the crossing between Helsinki and Tallinn

\begin{tabular}{|c|c|c|c|c|c|c|c|}
\hline \multirow{2}{*}{ Area } & \multicolumn{2}{|c|}{$\begin{array}{c}\text { Number of } \\
\text { candidates per } \\
\text { year }\end{array}$} & $\begin{array}{c}\text { Causati } \\
\text { on } \\
\text { probabi } \\
\text { lity }\end{array}$ & \multicolumn{2}{c|}{$\begin{array}{c}\text { Probability of } \\
\text { collisions per year }\end{array}$} & \multicolumn{2}{c|}{$\begin{array}{c}\text { Collision } \\
\text { reoccurrence in } \\
\text { years }\end{array}$} \\
\cline { 2 - 8 } & Summer & Winter & & Summer & Winter & Summer & Winter \\
\hline Cross SE & 111.0 & 92.3 & $1.3 \cdot 10^{-4}$ & 0.014 & 0.012 & 76.6 & 90.3 \\
\hline Cross SW & 79.0 & 65.8 & $1.3 \cdot 10^{-4}$ & 0.010 & 0.010 & 112.2 & 131.8 \\
\hline Cross NE & 88.5 & 79.2 & $1.3 \cdot 10^{-4}$ & 0.012 & 0.010 & 101.0 & 110.0 \\
\hline CrossNW & 111.3 & 106.2 & $1.3 \cdot 10^{-4}$ & 0.014 & 0.014 & 82.3 & 87.5 \\
\hline Overtk E & 155.4 & 153.7 & $4.9 \cdot 10^{-5}$ & 0.0077 & 0.0075 & 131.0 & 133.3 \\
\hline Overtk W & 197.5 & 199.5 & $4.9 \cdot 10^{-5}$ & 0.010 & 0.010 & 105.0 & 103.5 \\
\hline $\begin{array}{c}\text { Head-on } \\
\text { for W }\end{array}$ & 265.0 & 251.3 & $4.9 \cdot 10^{-5}$ & 0.011 & 0.011 & 106.0 & 91.0 \\
\hline $\begin{array}{c}\text { Head-on } \\
\text { for E }\end{array}$ & 195.5 & 219.8 & $4.9 \cdot 10^{-5}$ & 0.011 & 0.011 & 95.0 & 92.0 \\
\hline
\end{tabular}

Table 3. Estimate of annual accidental oil spill volume for double hull tankers in the crossing between Helsinki and Tallinn

\begin{tabular}{|c|c|c|}
\hline \multirow[t]{2}{*}{ Meeting type } & \multicolumn{2}{|c|}{ Accidental oil spill volume [t] } \\
\hline & Summer traffic & Winter traffic \\
\hline Crossing S-E & 15.8 & 12.3 \\
\hline Crossing S-W & 10.7 & 8.7 \\
\hline Crossing N-E & 12.1 & 10.9 \\
\hline Crossing N-W & 15.5 & 14.5 \\
\hline Overtaking E & 7.0 & 6.7 \\
\hline Overtaking W & 9.1 & 8.9 \\
\hline $\begin{array}{l}\text { Head-on for W- } \\
\text { bound tankers }\end{array}$ & 4.4 & 4.5 \\
\hline $\begin{array}{l}\text { Head-on for E- } \\
\text { bound tankers }\end{array}$ & 4.2 & 4.3 \\
\hline Total & 78.8 & 70.8 \\
\hline
\end{tabular}

The probability of spills of given magnitude were estimated from distribution described by equation (5), and the obtained results are presented in Table 4. To estimate the costs of an oil spill of certain size the Monte 
Carlo simulations were adopted, and the continuous distributions that fitted best the obtained data and used for further modelling are tabulated below.

Table 4.The parameters of distribution oil outflow in case of collision for certain types of tankers

\begin{tabular}{|c|c|c|c|c|c|c|}
\hline \multirow{2}{*}{$\begin{array}{c}\text { Oil spill } \\
\text { size in } \\
\text { tons }\end{array}$} & $\begin{array}{c}\text { Probabili } \\
\text { ty of oil } \\
\text { spill of } \\
\text { given } \\
\text { size }\end{array}$ & $\begin{array}{c}\text { Cost of oil spill of } \\
\text { given size modelled } \\
\text { by following } \\
\text { distribution: }\end{array}$ & \multicolumn{2}{|c|}{$\begin{array}{c}\text { Probability of } \\
\text { collision }\end{array}$} & $\begin{array}{c}\text { Probabil } \\
\text { ity of } \\
\text { spill } \\
\text { given } \\
\text { accident }\end{array}$ \\
\cline { 3 - 6 } & $\mathrm{P}_{\text {OS }}$ & Summer & Winter & Summer & Winter & PA \\
\hline $0-500$ & 0.098 & Beta & Beta & 0.091 & 0.076 & 0.14 \\
\hline $500-1 \mathrm{k}$ & 0.084 & Unif & Unif & 0.091 & 0.076 & 0.14 \\
\hline $1 \mathrm{k}-5 \mathrm{k}$ & 0.388 & Beta & Unif & 0.091 & 0.076 & 0.14 \\
\hline $5 \mathrm{k}-10 \mathrm{k}$ & 0.190 & Beta & Beta & 0.091 & 0.076 & 0.14 \\
\hline $10 \mathrm{k}-30 \mathrm{k}$ & 0.179 & Triang & Beta & 0.091 & 0.076 & 0.14 \\
\hline $30 \mathrm{k}-60 \mathrm{k}$ & 0.061 & LogNrm & Exp & 0.091 & 0.076 & 0.14 \\
\hline
\end{tabular}

The risk that was posed by tankers involved in collisions in the analyzed area, in the yearly perspective, calculated for summer traffic is presented in Fig. 9 and for winter traffic in Fig. 10. The risk is expressed in USD, and distributions that fitted best the calculated discrete data were as follows: the LogNormal distribution for summer traffic and the Gamma distribution for winter traffic.The parameters of these distributions and the distributions are presented in the graphs below.
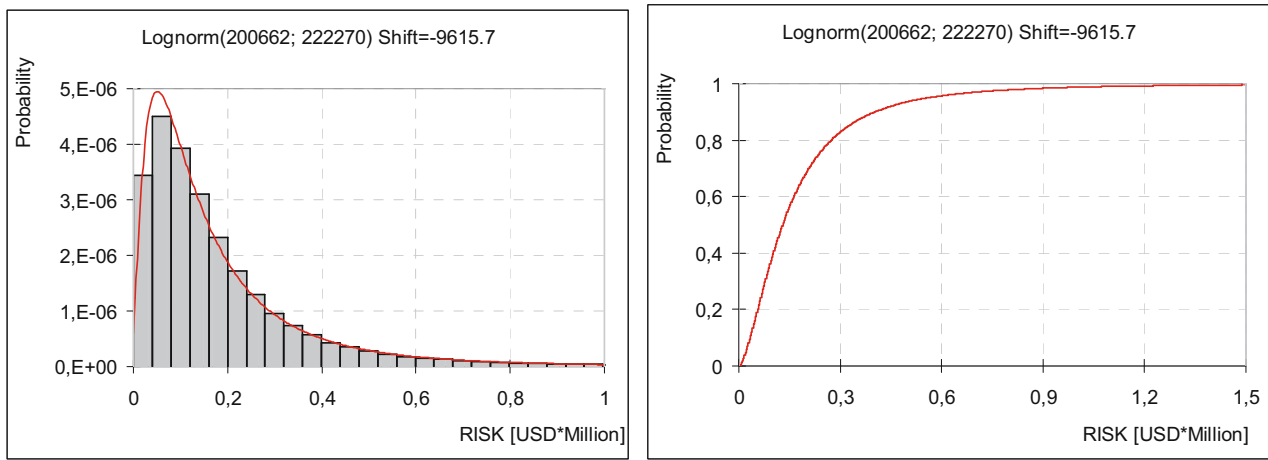

Fig. 9. Probability and cumulative density functions of variable "risk" in case of tankers collision in the GOF, summer traffic 
Predykcja ryzyka kolizji tankowców......
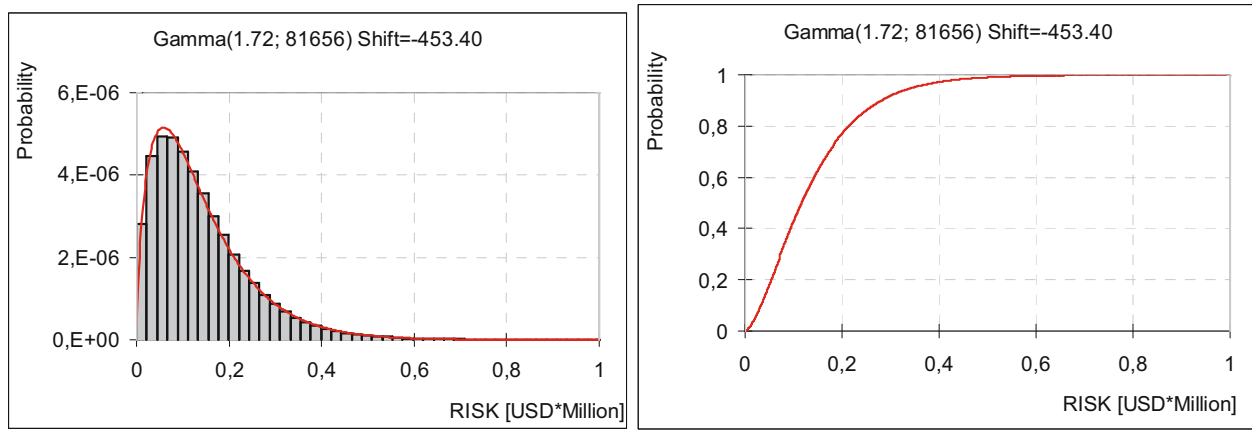

Fig. 10. Probability and cumulative density functions of variable "risk" in case of tankers collision in the GOF, winter traffic

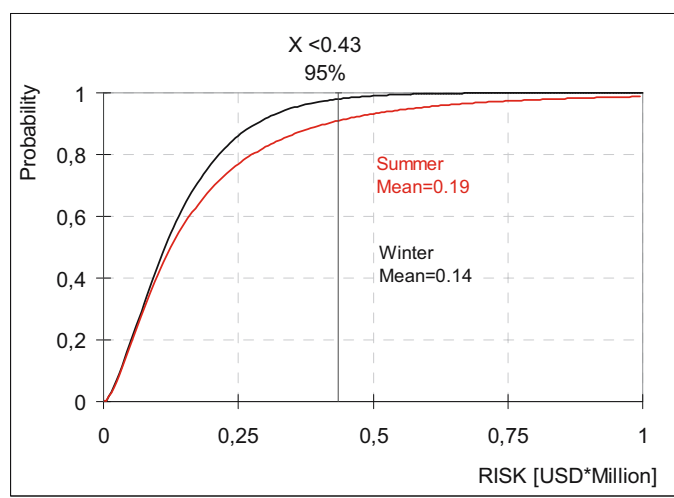

Fig. 11. Cumulative density functions of risk due to tankers collisions in the HelsinkiTallinn crossing for summer and winter traffic

The risk of collision for tankers in case of summer traffic $\left(R_{S}\right)$ was defined by Lognormal distribution, which satisfies the following equations:

$$
R_{S}=f(x)=\frac{1}{x \sqrt{2 \pi \sigma^{\prime}}} e^{-0.5\left[\frac{\ln x-u^{\prime}}{\sigma^{\prime}}\right]^{2}}
$$

where $x$ is a random variable "risk" in case of collision, $\mu$ ' and $\sigma$ ' were defined as follows:

$$
u^{\prime} \equiv \ln \left[\frac{\mu^{2}}{\sqrt{\sigma^{2}+\mu^{2}}}\right] \text {, and } \sigma^{\prime} \equiv \sqrt{\ln \left[1+\left(\frac{\sigma}{\mu}\right)^{2}\right]} \text {, }
$$


where $\mu$ equals 200662, and $\sigma$ equals 222270. Whereas the risk of collision in case of winter traffic $\left(R_{W}\right)$ was described by Gamma distribution, which follows the equation:

$$
R_{W}=f(x)=\frac{1}{\beta \Gamma(\alpha)}\left(\frac{x}{\beta}\right)^{\alpha-1} e^{--\frac{x}{\beta}}
$$

where $\beta$ equals 81656, $\Gamma(\alpha)$ is the Gamma Function, and $\alpha$ equals 1.72 .

\section{Conclusions}

The paper presents the risk models for marine traffic in the selected area of the Gulf of Finland in general and for oil transportation in particular. The risk is expressed as a product of probability of accident (collision of a tanker) and its consequences (cleaning costs of an oil spill). The probabilities of collision were assessed by means of an innovative model developed by the author.

The model used for probability of an oil spill size assessment was based on modified IMO methodology, which was adjusted to the tankers fleet that operates in the Baltic Sea. The costs of an oil spill were estimated with use of the state-of-the-art, statistic based model.

The risk was calculated for a busy waterways junction in front of Helsinki harbour, where east-west waterways crossed north-south lines, which comprised mostly of passenger ferries. The risk calculated in this study was given in the yearly perspective and was assessed for collisions in which at least one tanker was involved. The obtained risk values for tankers involved in collision in the waterways junction were assessed for summer and winter traffic profiles individually, and the seasonal differences may be noticed. The risk was expressed in a form of probability density functions, obtained by means of Monte Carlo simulations, thus the uncertainties of the input values were taken into account.

The cost model applied did not take into consideration the season of a year, thus the traffic composition was the only factor that made a difference between winter and summer risk values. Due to a significant difference between summer and winter navigational conditions in the GOF it shall be investigated if the oil spill costs are not season dependent, and if it is justified to consider them equal for summer and winter conditions. 
Predykcja ryzyka kolizji tankowców......

Acknowledgments: DSc Erik Sonne Ravn from Danish Maritime Administration is thanked for his help to evaluate the ship traffic pattern in the approach to Sköldvik harbour. The authors appreciate the financial contributions of the following entities: the EU, Baltic Sea Region (this research was partly founded by EfficienSea project), the city of Kotka and the Finnish Ministry of Employment and the Economy.

\section{References}

1. Det Norske Veritas: Formal Safety Assessment - Large Passanger Ships, ANNEX II: Risk Assesment - Large Passenger Ships - Navigation. 2003.

2. Hanninen M, Kujala P.: The effects of causation probability on the ship colliion statistics in the Gulf of Finland. 8th International Navigational Symposium on Marine Navigation and Safety of Sea Transportation, Balkema (2009).

3. Kontovas C., Psarafitis H.: Marine Environment Risk Assessment: A Survey on the Disutility Cost of Oil Spills. 2nd Int. Symposium on Ship Operations,Management and Economics, Society of Naval Architects and Marine Engineers (2008).

4. Kujala P, Hänninen M, Arola T, Ylitalo J.: Analysis of the marine traffic safety in the Gulf of Finland. Reliability Engineering \& System Safety 94, 8 (2009), 1349-1357.

5. Kuronen J, Tapaninen U, Helminen R, Lehikoinen A.: Maritime transportation in the Gulf of Finland in 2007 and in 2015. Center for Maritime Studies, Turku, 2008.

6. Marine Board and Transport Research Board: Environmental Performance of Tanker Designs in Collision and Grounding: Method for Comparision -Special Report 259. National Academy Press, Washington D.C., 2001.

7. Montewka J. Kujala P, Ylitalo J.: The quantitative assessment of marine traffic safety in the Gulf of Finland, on the basis of AIS data. Marine Traffic Engineering 2009, Maritime University of Szczecin (2009).

8. Mäkinen A.: WWF Suomi. 2003. http://www.wwf.fi/tiedotus/tiedotteet/ tiedotteet 2003/ccb itamerelle saatava.html.

9. Nikula P, Tynkkynen V.: Risk in oil transportation in the Gulf of Finland. Not a question of if - but when. University of Helsinki \& Nordic Centre for Spatial Development, Helsinki, 2007.

10. Papanikolaou A.: Risk-Based Ship Design. Springer, 2009.

11. Rytkönen J.: Archive $2005<$ Expert articles $<$ Baltic Rim Economies $<$ Economic monitoring $<$ Pan-European Institute $<$ Special Units $<$ Units $<$ Turku School of Economics. 2005.

http:/www.tse.fi/EN/units/specialunits/pei/economicmonitoring/bre/articles/ar chive2005/Pages/default.aspx.

12. Seppälä T.: Estimation of accidental oil outflow for tankers operating in the Baltic Sea. Literature review. Unpublished report. TKK, Espoo, 2009. 
13. Smailys V, Česnauskis M.: Estimation of expected cargo oil outflow from tanker involved in casualty. Transport Vilnius 21, 4 (2006), 293-300.

14. Trans Alaska Pipeline System Owners: Oil Spill analysis for North Slope Oil Production and Transportation Operations. In Environmental report for Trans Alaska Pipeline System Right-of-Way Renewal. 2001.

15. Vinnem J.: Offshore Risk Assessment. Springer London, 2007.

16. Yamada Y.: The Cost of Oil Spills from Tankers in Relation to Weight of Spilled Oil. Marine Technology 46, (2009), 219-228.

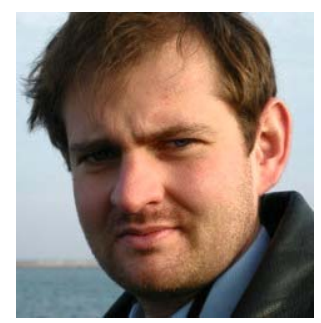

Jakub Montewka, PhD, Nautical Officer (Management Level), Associated Fellow of Royal Institute of Navigation in London is a researcher and project manager at Helsinki University of Technology (TKK) at Marine Technology Unit. The primary field of interests is a maritime traffic safety and maritime risk modelling with emphasis put on probability of collision and grounding modelling. At present he is a coordinator of EU project EfficienSea at TKK, in which extensive works on risk algorithm development based on AIS data are carried out. He graduated in Navigation from Maritime University of Szczecin in 2001. At the same University he got his doctorate in 2008. In his free time is a fan of family excursions, photography, cycling, diving, skiing and most kinds of outdoor activities. 